\title{
Cambial Cell Production and Structure of Xylem and Phloem as an Indicator of Tree Vitality: A Review
}

\author{
Jožica Gričar \\ Department of Yield and Silviculture, Slovenian Forestry Institute \\ Slovenia
}

\section{Introduction}

One third of Europe's land surface is covered by forests, with important economic and social value. They constitute the most natural ecosystems of the continent. Natural biotic and abiotic disturbances affect their structure and composition. Sustainable forest management and environmental policies rely on the sound scientific resource provided by long-term, large scale and intensive monitoring of forests. Long-living trees and ecosystems are suitable for studying the impact of human factors as opposed to the effects of natural system variability. Forest monitoring helps to improve our knowledge of the state of forests and to quantify changes that are taking place within forests and related ecosystems. Information about forest ecosystem functions and processes is, however, also necessary to gain an understanding of the causes underlying such changes and, subsequently, to model the future effects of natural and anthropogenic stress factors on our forests and understand the adaptation potential of forests to the effects of environmental change and air pollution (UNECE, 2008).

The vitality of trees is one of the most important indicators of forest condition and can be characterized by different parameters, such as assessment of the crown condition, tree growth etc. (UN-ECE, 2008). However, the latest studies show that cambium activity and increments of its products - secondary phloem and secondary xylem (wood) - reflect the vitality of trees (Gričar et al., 2009). In the different vitality of silver firs (Abies alba Mill.), it has been demonstrated that data on phloem increment structure, the relationship between the phloem and wood increment and the number of cambial cells in the dormant state are very useful in the assessment of the health condition of trees.

This review focuses in particular on presenting the potential of structure and width of xylem, phloem and cambium in the case silver fir and pedunculate oak, as indicators of the vitality status of trees. Forest monitoring and indicators of tree vitality status will be briefly summarized. Growth ring patterns have proved to be an appropriate tool for quantifying the response of a forest stand to changing environmental factors, so wood formation processes that determine the structure of wood and its quality will be described in more detail. Finally, tree vitality has a major influence on wood quality. Two examples, silver fir and pedunculate oak, will therefore be demonstrated. 


\section{Forest monitoring}

Only healthy and vital forests can serve multiple ecological, social and productive roles, as understood by the modern world. To be able to acquire a reliable assessment of the state and changes in forest ecosystems and at least partly to explain and understand the most important processes occurring in them, forest monitoring programmes have been implemented worldwide (e.g., International Co-operative Programme on Assessment and Monitoring of Air Pollution Effects on Forests - ICP Forests, Acid Deposition Monitoring Network in East Asia - EANET, Forest Health Monitoring - FHM). Monitoring is essential in order to obtain information about the condition of natural resources, their development over time and space, and to study their relationships with biotic/abiotic factors (Ferretti, 2009). Environmental and nature management, namely, cannot operate effectively without reliable information on changes in the environment and on the causes of those changes. There is therefore considerable concern in the scientific community about the ability of monitoring programmes to provide the desired information (Legg \& Nagy, 2006; Vos et al., 2000). Some researchers believe that many operational monitoring programs are not very effective or useful for decision-making (Vos et al., 2000). The main reason for this is poor confidence in the quality of the data, with the most typical questions raised about the statistical basis of sampling design, the reliability and comparability of data and data management (e.g., Ferretti, 2009; Legg \& Nagy, 2006; Vos et al., 2000). The results of inadequate monitoring are misleading in terms of their information quality and are dangerous because they create the illusion that something useful has been done (Legg \& Nagy, 2006).

Indicators of tree health and vitality need to be accurate and reliable, but also cheap and easy to use (Martín-García et al., 2009). The quality of monitoring is thus defined by its ability to provide data that allow estimates of the status of the target resource with the defined precision level, permit the detection of change with the defined power, and are comparable through space and time. Despite considerable work on data quality control, parts of the monitoring process are still poorly covered by quality assurance and have revealed weaknesses in design and implementation. Steps towards a more comprehensive quality assurance approach have currently been undertaken (Ferretti, 2009).

\section{ICP Forests}

In Europe, the International Co-operative Programme on the Assessment and Monitoring of Air Pollution Effects on Forests (ICP Forests) was established in 1985. The system combines an inventory approach with intensive monitoring. It provides quality assured and representative data on forest ecosystem health and vitality and helps to detect responses of forest ecosystems to the changing environment. Air pollution effects are the particular focus of the programme. ICP Forests uses two complementary monitoring approaches on the European level. Representative monitoring (Level I) is based on around 6,000 permanent observation plots and provides an annual overview of forest condition on the European level. Intensive monitoring (Level II) on around 500 sites provides insight into factors affecting the condition of forest ecosystems and into the effects and interactions of different stress factors. These plots are located in forests that represent the most important forest ecosystems of the continent. The programme provides an early warning system for the impact of environmental stress factors on forest ecosystem health and vitality. Although forest species have responded to environmental changes throughout their evolutionary 
history, a primary concern in relation to wild species and their ecosystems is the rapid rate of human induced changes (UN-ECE, 2008).

\section{Vitality of forest and trees}

Though the vitality of trees is one of the most important indicators of forest condition, forest health cannot be assessed solely on the basis of tree condition, since forest consists of more than trees (Innes, 1993). Tree vigour is best restricted as a term to the growth of trees in relation to a hypothetical optimum, whereas tree health is defined in the pathological sense as the incidence of biotic and abiotic factors affecting the tree within a forest. Tree condition is less specific, referring to the overall appearance of trees within the forest. The health of a tree can be evaluated by such indicators as crown condition, growth rate and external signs of disease-causing agents (Kolb et al., 1994).

Tree vitality cannot be measured directly, only through several indicators, such as assessment of the crown condition, growth of bud, stem (radial or height) and root systems, measurements of cambial electrical resistance or the size and shape of needles etc. (Dobbertin, 2005). Shigo (1986) defines vigour as the capacity of a tree to resist strain. It determines the potential strength against any threats to survival. It is genetically derived and cannot therefore be changed. Tree vitality, on the other hand, is the dynamic ability of a tree to grow under the conditions present. It is important to assess the influence of external stress, since resistance to stress is an important criterion in the vitality concept (Dobbertin, 2005). Larcher (2003) defines stress as a significant deviation from the condition optimal for life. Vitality becomes weaker as stress persists. At a certain point, the capacity of a tree to overcome further stress or to survive diminishes, i.e., vitality decreases. Irreversible damage or tree death can occur. The hypothetical optimal tree vitality is not known; only the minimum vitality (i.e., tree death) can be identified (Dobbertin, 2005).

The consequences of tree death, in terms of effects on other ecosystem components and processes, depend on many variables, including the species, mortality agent, position, spatial pattern (dispersed or aggregated) and numbers that have died. Tree death is an important indicator of ecosystem health and can assist recognition of stresses caused by pollutants, such as acid rain and ozone. However, the value of tree death as an indicator of anthropogenic disturbance depends on a thorough understanding of the patterns of tree death under natural conditions. At the present time, adequate understanding of this is woefully lacking. Tree death also demonstrates some principles of ecological processes: the importance of defining the spatial and temporal context of a study, the importance of stochastic processes, and the fact that most ecological processes are driven by multiple mechanisms and that the relative importance of these mechanisms changes over time and space, and the importance of the natural histories of species and ecosystems. Tree death illustrates that many valid and useful perspectives on a single, presumably simple process exist. Furthermore, it makes clear that we need to give more consideration to the biology of organisms and ecosystems in developing, evaluating and applying theoretical constructs (Franklin et al., 1987).

It is not possible to estimate forest health condition from concepts developed at the individual organism level and simply to apply them on a landscape level (Kolb et al., 1994). In other words, extension of this concept to a complex system, such as a forest, is based on making an analogy between the functioning of an organism and an ecosystem. A dead or dying tree is not healthy. The health of a stand must take into account many more 
dimensions than the health of a tree. The health of a stand relates to the management objectives for that stand (utilitarian perspective) and to the long-term functioning of the organisms and trophic networks that constitute the stand (ecosystem perspective). Tree mortality in a stand would not indicate an unhealthy condition as long as the rate of mortality was not greater than the capacity for replacement. Stand objectives such as wildlife habitat, soil and water protection and preservation of biodiversity do not require that all trees be healthy. A dead tree is not healthy but it may be part of a healthy stand. The health of a forest ecosystem or landscape is similarly more complex than the health of a stand (Kolb et al., 1994).

\section{Indicators of tree vitality status}

Biochemical indicators on the plant cell level, such as phytohormones or enzymes, may best reflect the reaction of trees to various environmental stresses (Larcher, 2003). Unfortunately, many such indicators cannot readily be extracted in the field or are very expensive. Several indicators, such as assessment of the crown condition, growth of bud, stem (radial or height) and root system, measurements of cambial electrical resistance or size and shape of needles etc. may instead be used (Dobbertin, 2005).

Crown condition is a major indicator of forest health in Europe. The condition of forest trees in Europe is monitored over large areas by a survey of tree crown transparency and discoloration, which is a fast reacting indicator of numerous natural and anthropogenic factors affecting tree vitality. Crown transparency and discoloration is a valuable indicator of the condition of forest trees. It reflects, among other factors, weather conditions and the occurrence of insects and fungal diseases. Such information is extremely relevant for monitoring the reactions of forest ecosystems to climate change and for ensuring sustainable forest management in the future (UN-ECE, 2008).

Crown condition assessments are commonly used in monitoring programs, since they are quick, easy and cheap to do. However, interpretation of these data may be complicated by the occurrence of strong fructification years in some tree species, when the foliage is reduced (Beck, 2009). In addition, tree crown transparency and discoloration used to be visually estimated by observers from the ground, raising the questions about the subjectivity of human assessment, data quality and comparability across the countries (Mizoue \& Dobbertin, 2003). These issues were tried to be solved by combining field and control team assessments, using data from cross-calibration courses to estimate correction factors, using reference photographs or standard sets of two-dimensional silhouettes representing various degrees of foliar density (Frampton et al., 2001; Ghosh \& Innes, 1995; Innes et al., 1993; Solberg \& Strand, 1999). Nevertheless, since these improvements were sometimes not enough, the researchers started to replace visual ground assessment by digital photo (Martín-García et al., 2009; Mizoue, 2002) or by remote sensing techniques (Coops et al., 2004; Stone et al., 2003)

Moreover, it is not possible simply to conclude tree vitality by crown condition. Growth rates can be considerably reduced while foliage is still inconspicuous (Beck, 2009). In particular, the relation between crown condition and xylem increment in trees has not been satisfactorily explained. In principle, physiological investigations of these relationships through case studies may be useful for improving our understanding.

As summarised by Kozlowsky \& Pallardy (1997), the requirements for tree growth are carbon dioxide, water, and minerals for raw materials, light as an energy resource, oxygen 
and favourable temperature for growth processes. The capacity of photosynthetic processes (i.e., foliar biomass) and competition for resources are constraining factors for tree growth. Tree growth processes can be ranked by order of importance as foliage growth, root growth, bud growth, storage tissue growth, stem growth, growth of defence compounds and reproductive growth (Waring, 1987; Waring et al., 1980). Under stress, photosynthesis is reduced and carbon allocation is altered. Stem growth may be reduced early on, since it is not directly vital to the tree. Comparison with a suitable reference is important for any potential vitality indicator. Depending on the aim of the study, the references used can be the growth of trees presumed to be without stress. The general disadvantage is that no absolute growth reference is available. Some stresses, such as competition, root rot or mistletoe occurrence, affect the tree over extended time periods, whereas other stresses, such as drought or insect defoliation, cause immediate reactions. Annual or inter-annual stem growth assessment is therefore needed in long-term monitoring plots. Tree growth can serve as a vitality indicator if a reference growth or growth trends are available (Dobbertin, 2005). It is noteworthy that not every stress is necessarily negative for trees but can instead induce increased resistance to stress (Kozlowsky \& Pallardy, 1997; Larcher, 2003). A short-term stress reaction may therefore not coincide with a long-term change in tree vitality. Growth changes must thus be interpreted on a long-term perspective (Dobbertin, 2005).

\section{Growth ring patterns as indicators of tree health}

Beck (2009) emphasized dendroecological analysis of tree and stand growth patterns as an appropriate tool for quantifying the response of a forest stand to changing environmental factors. Tree growth parameters, which reflect changing growth conditions year by year, are very important. Such parameters of tree vigour presented as a time series retrospectively enable an insight into the growth history of the stand. Namely, tree-ring analysis can provide information on trees and stand development in the past. The growth of trees and site history of a stand can be reconstructed using tree-ring time series, which contain lots of information on environmental conditions and their impact on the growth of trees. Wood formation is the final result of the complete metabolic balance. It is the share of the balance of matter produced by the foliage, respiration and the higher priorities of allocation to other tree organs (roots, fruits etc.), which has not been consumed elsewhere. This remaining share refers directly to the state of the reserve pool. The amount of new wood formation can therefore be understood as a suitable tree health indicator. In contrast to visually assessed crown condition, tree-ring widths are measured (qualitative) data. Subjective estimation is thus eliminated (Beck, 2009).

Tree growth rates are affected by both pollutants and climatic stress. In view of this complexity, a comprehensive dendroecological analysis of tree and stand growth patterns is considered to be an appropriate tool for quantifying the response of a forest stand to changing environmental factors. The inclusion of dendroecological methods in monitoring programs provides many advantages and new findings. The elaboration and analysis of tree ring networks (chronologies well scattered with respect to space and altitude) are currently seen as successful fields of ecological research. Ongoing depositions and increasing climatic stress urgently require the quantification of the growth response of forests as an indicator of tree and stand vigour (Beck, 2009).

Decreasing growth curves are among the most obvious growth-related characteristics of dying trees, which is not only a species-specific but also a site-specific feature. A 
combination of growth levels or relative growth and growth trends has been shown to increase the reliability of mortality predictions. Abrupt declines in growth or strongly negative growth trends may indicate a rapid physiological adaptation to changed environmental conditions (Bigler et al., 2004). Reduced xylem increments, as one of the first indicators of decreased tree vitality, are very useful for reconstruction of past tree vitality and evaluation of mortality risk (Bigler \& Bugmann, 2004; Bigler et al., 2004). These assessments of individual tree vitality and accurate mortality predictions may be used in forest management to identify and selectively cut low-vitality trees, so as to release the remaining healthy trees (Bigler et al., 2004).

\section{The role of cambium in a tree}

The growth of trees, leading to an increase in the size and mass of an organism, occurs only in specific areas, so called meristems, and involves cell division, expansion and differentiation. Cell division is an essential part of growth, resulting in an increase in the number of cells. In the expansion phase, cells increase in size. The cytoplasm grows and the vacuole fills with water, which exerts pressure on the cell wall and causes it to expand. In the next step, cells differentiate, or specialize, into various cell types. A tree is composed of various cell types that perform different functions required in a multicellular organism (Berg, 2008).

Meristems consist of actively dividing undifferentiated cells, which retain the capacity for growth through their entire lifespan. Two kinds of meristematic growth occur in trees; primary or extensional and secondary or lateral (Berg, 2008). Primary growth occurs as a result of the activity of apical meristems, which are located at the tips of stems and roots and lead to an increase in a tree's length and development of various tissues: epidermis, cortex, conducting veins, pith and leaves (Fig. 1) (Mauseth, 1988). In woody plants, even in the first year of growth the primary tissues of stems and roots are replaced by secondary tissues formed by the secondary lateral meristems: vascular cambium (in short cambium) and cork cambium (phellogen). The activity of secondary meristem is expressed as radial growth, which allows the increase of the volume of the conducting system and the formation of mechanical and protective tissues (Plomion et al., 2001; Taiz \& Zeiger, 2002). Cambium produces secondary vascular tissues, which conduct water and nutrients and provide support. Cork cambium produces protective tissue (periderm), which protects the stem and root from water loss, pathogens, and herbivorous insects (Larson, 1994; Panshin \& de Zeeuw, 1980).

The cambium, as an uninterrupted, thin layer ring, lies between the secondary xylem on the inner side and secondary phloem on the outer side, the two tissues it produces (Larson, 1994; Mauseth, 1988). It has been called the "least understood plant meristem", because of the associated technical difficulties when working with trees (Groover, 2005).

The cambium consists of a layer of cells that divide actively, have small radial dimensions and have no intercellular space (Savidge, 2001). It differs from other meristems by two types of highly vacuolised cells: short, rather isodiametric ray cells, from which radial rays are formed, and elongated fusiform or spindle-shaped cells, which form axial elements (Fig. 2). New cambial cells are formed by anticlinal divisions, which ensures an increase in girth of the cambium. The cambium has a decisive role in radial growth and the development of trees, since new vascular tissues of xylem and phloem are formed through periclinal or additive divisions that occur in the tangential plane, by which the diameter of the tree 
increases. The production of secondary conductive tissues represents approximately $90 \%$ of all mitoses (Lachaud et al., 1999; Larson, 1994).

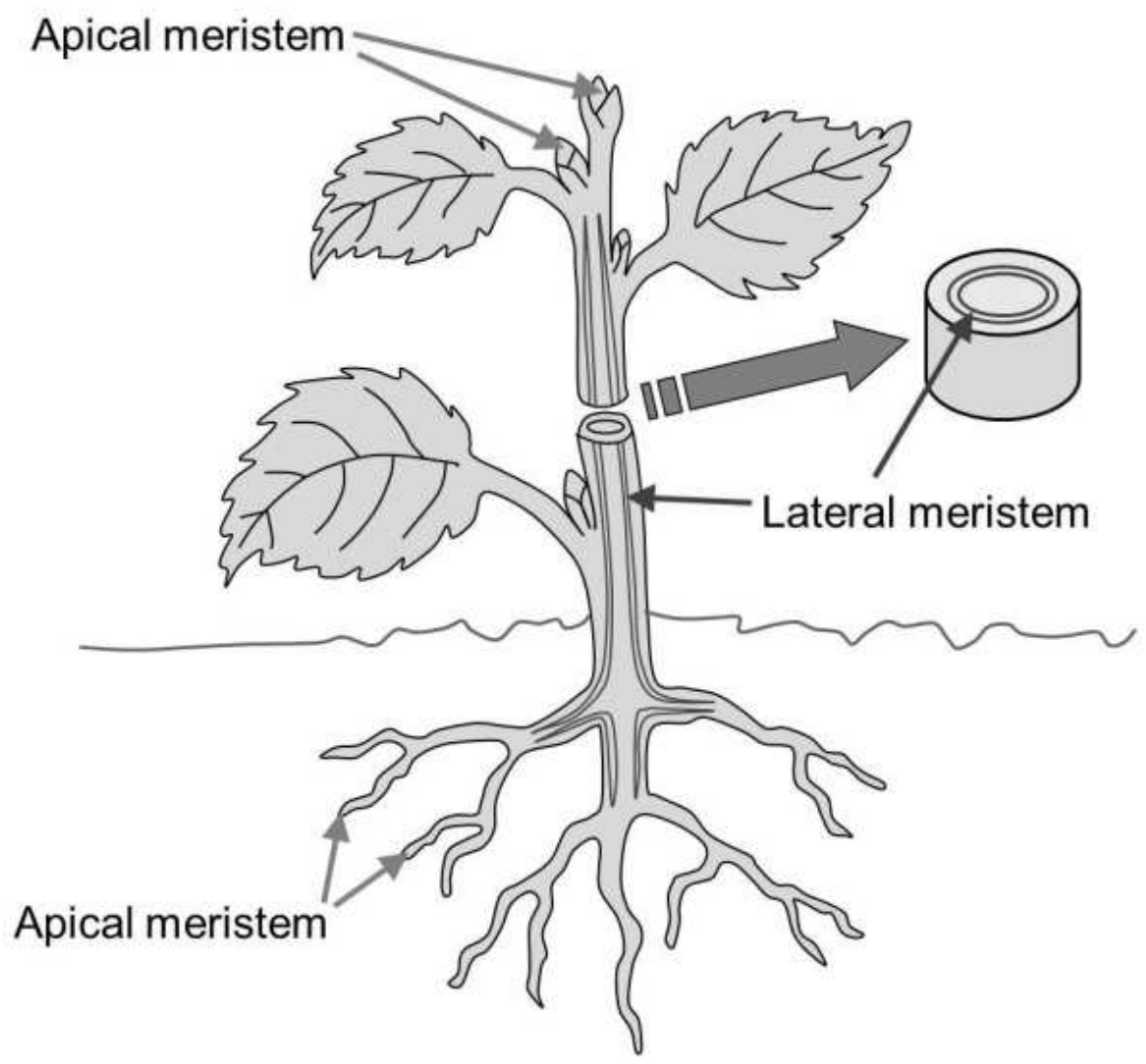

Fig. 1. Location of apical and lateral meristems in a plant.

A characteristic of tree species in the temperate climatic zone is a seasonal alternation of cambial activity and dormant (resting) periods, which is generally related to alternations of cold and hot or rainy and dry seasons (Larcher, 2003). Cambial activity usually starts in spring with cell division and ends in late summer with the completed development of the latest newly formed cells (Fig. 2). At the beginning of cambial activity, the number of cambial cells increases and they start to divide, which is followed by differentiation of derivatives into the adult elements of xylem or phloem. In the process of differentiation, which includes post-cambial cell growth, deposition of the secondary cell wall and - in wood tracheids, fibers and vessels - also lignification and programmed cell death, the cells specialize in order to perform their functions (Fig. 3) (Plomion et al., 2001). The vascular system in trees is very complex, composed of various types of cells, which are differently orientated (Chaffey, 2002). 

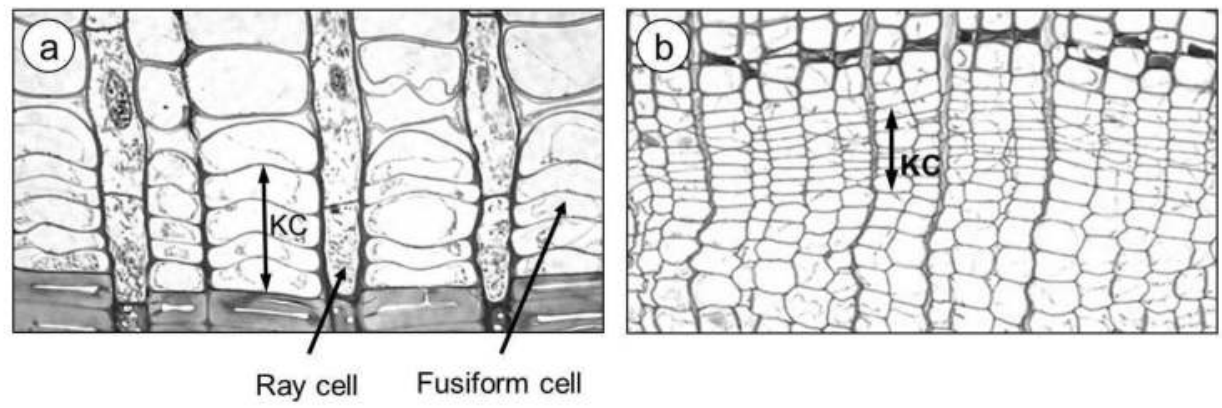

Fig. 2. (a) Dormant and (b) active cambium. KC - cambial cells

1. Cell divison in a cambium

2. Cell expansion

3. Secondary wall formation

4. Lignification

\section{Programmed cell death}
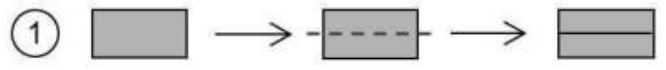

(2)
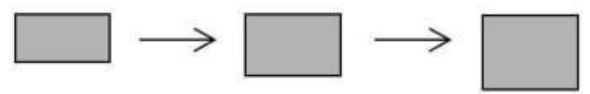

(3)
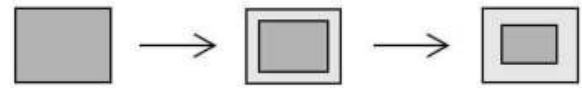

(4)
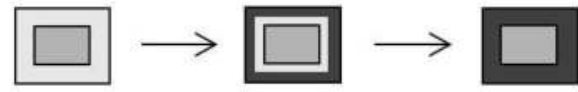

(5)
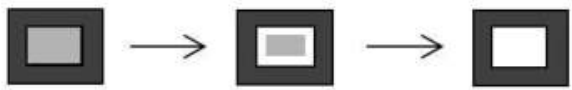

Fig. 3. Schematic illustration of formation of tracheid from cambial cell in conifers.

\section{Wood and phloem formation}

Xylo- and phloemogenesis are periodic processes driven by a variety of internal and external factors, the influence of which changes during the growing season. Xylem and phloem increments are not predetermined, but are plastic end-products of interactions between the genotype and the environment (Savidge, 2001). The environment determines the physical conditions and the energy for xylo- and phloemogenesis. The external factors affect the onset, end and rate of individual growth processes, which determine the morphology of cells (Wodzicki, 2001). Xylo- and phloemogenesis lead to specialization of cells in terms of their chemical composition, morphological characteristics and function. Cell divisions in the cambium and post-cambial growth determine the width of the annual xylem and phloem increment, and the deposition of the secondary cell wall (and lignification) determines the accumulation of biomass in the walls of the xylem and phloem cells (annual biomass increment) (Fig. 3) (Plomion et al., 2001).

The number of dormant cambial cells depends on several factors; such as tree species, tree age, part of the tree, and tree vigour and vitality. The cambium's cell production, under 
normal growth conditions, is more intensive on the xylem than on the phloem side. However, under physiologically very demanding conditions, the phloem increment can exceed the xylem one, which may not appear at all in exceptional cases (Larson, 1994; Panshin \& de Zeeuw, 1980).

Of all the secondary tissues, xylem and its formation is by far the most investigated, particularly due to its great economic and ecological importance. The width and structure of xylem growth rings is a source of information about past and present factors affecting the development processes in an individual tree (Fritts, 1976; Wimmer, 2002). The width of the xylem increment is closely related to its anatomical structure, which defines the physical and mechanical properties of wood and, consequently, its end-use (Fig. 4).

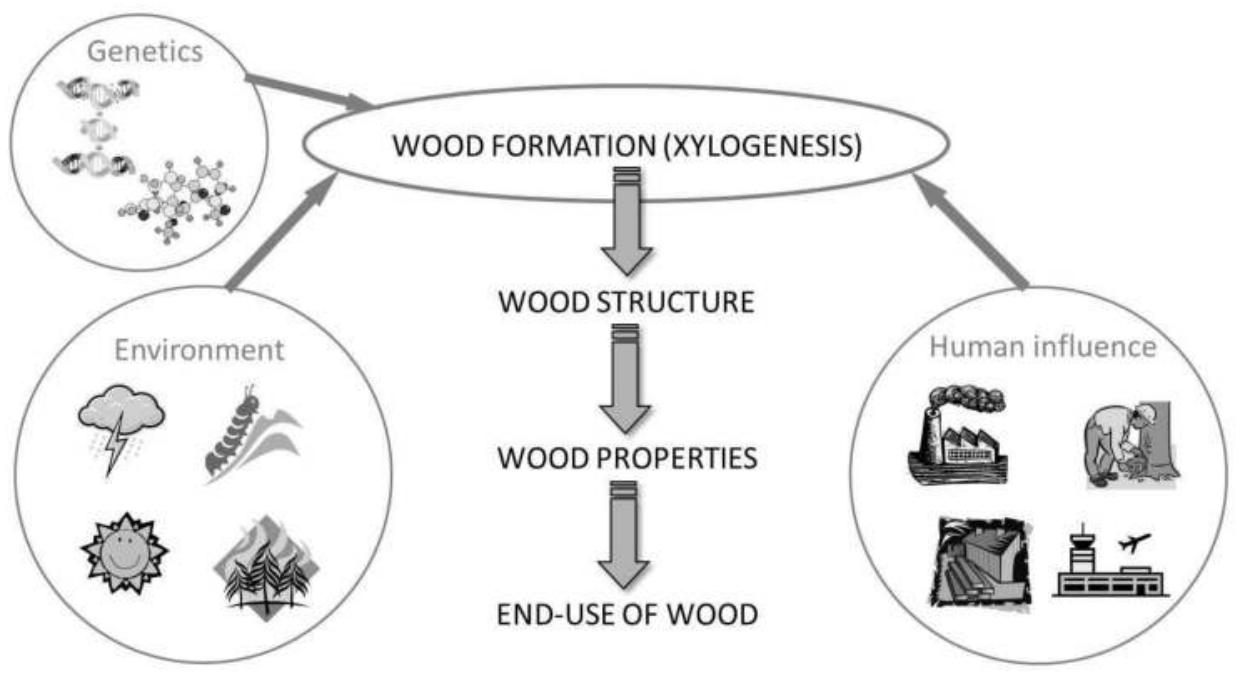

Fig. 4. Xylogenesis is affected by a variety of internal and external factors, which influence wood structure and properties and, consequently, the end-use of wood.

Studies of the seasonal dynamics of phloem growth rings are fewer, which can be partly explained by a lower interest in the commercial use of bark in comparison to the use of timber. In addition, the phloem increment is exposed to relatively fast secondary changes of the tissue, e.g., collapse, sclerification and inflation of axial parenchyma, so only the structure of one or two of the most recent phloem growth rings can be seen clearly. Older non-conducting tissue eventually collapses in a radial direction, deforms and later often also falls off and is thus not suitable for dendrochronological and dendroecological studies (Gričar, 2009).

Nevertheless, the seasonal dynamics of phloem formation is very important in studies of trees' radial growth because cambium is a bi-facial meristem, so studies of cambial activity and wood formation reveal only part of the information on cambial cell productivity during the growth season. Moreover, the processes of wood and phloem formation differ in terms of time and space, and internal and external influences affect the mechanisms of their 
formation differently. Phloem increment is more stable and less subjected to fluctuations of environmental conditions. Comprehensive studies are therefore vital for investigating the influence of specific climatic factors on the radial growth of trees.

The impact of changing environment will modify the seasonality and rate of growth, which can have an important effect on tree performance and survival and also on wood structure and properties and, consequently, on the end-use of wood.

\section{Wood density in relation to ring widths}

Wood formation determines the morphology of cells, the structure of the xylem growth ring and thus the wood properties. Xylem rings are composed of early wood and late wood. Early wood cells are formed at the beginning of the growing season and are characterized by a large radial dimension and thin cell walls. The development of late wood cells with small radial dimensions and thick cell walls occurs in summer, resulting in its higher density. In sapwood, the ratio between the density of early wood and late wood is 1: 2.3 in fir and 1: 4.0 in pine (Gorišek, 2009). In ring-porous deciduous tree species this ratio is about 1: 2.5 and in diffuse-porous trees much smaller, e.g., 1: 1.5 in beech (Gorišek, 2009).

Wood is heterogeneous material composed of various types of cells that perform different functions. Consequently, the density of wood is related to the morphological characteristics of the cells. Growth of trees from temperate climate regions is seasonal resulting in the formation of growth rings. At the beginning of the growing season the dominant function appears to be conduction, while in the second part of the season is support. Early wood cells have therefore thinner cell walls and bigger cavities than late wood ones. Hence, the greater is the proportion of late wood the greater are the density and strength. However, wood density and its strength are influenced by the ring width (Fig. 5) (Dinwoodie, 1981). This relationship is relatively complex; in ring-porous tree species, such as oak and ash, increasing ring width results in an increase in the percentage of late wood, which contains most of the fibres and, consequently, the density will increase (Fig. 6). In diffuse-porous tree

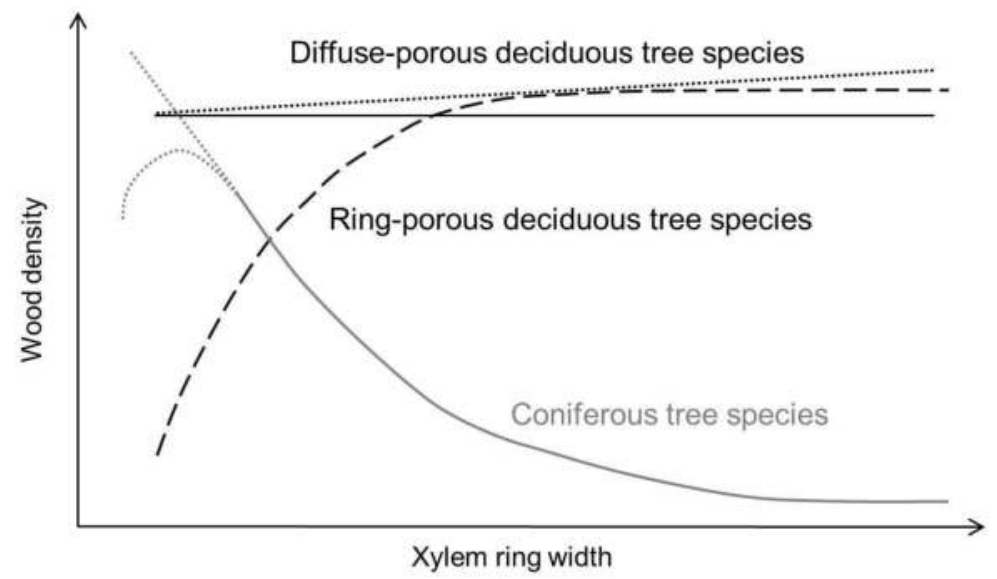

Fig. 5. Impact of xylem ring width on the density of wood in ring-porous and diffuse-porous deciduous trees and conifers. 

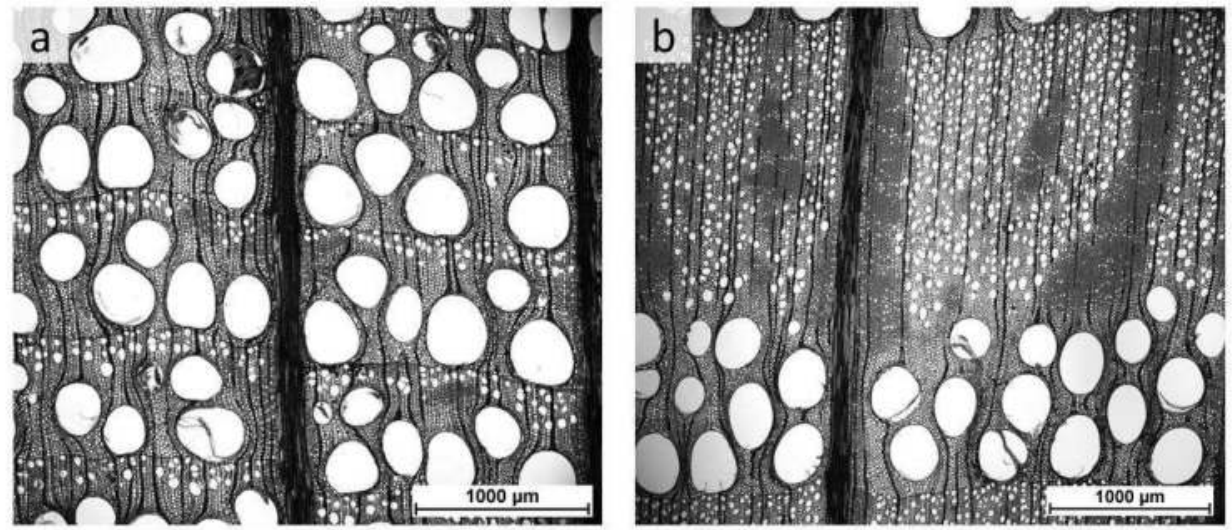

Fig. 6. Wood density is closely related to ring width in ring-porous oak; non-vital (a) and vital oak (b).

species (beech and maple, for example), in which the wood anatomical structure in the xylem ring is relatively homogenous, increasing ring width has almost no effect on wood density. In softwoods, however, increasing ring width results in an increased percentage of low-density early wood and, consequently, a decrease in density (Fig. 7). Exceptionally, softwoods from very cold areas may have narrow rings with low density, because late wood formation is restricted by the short summer period (Dinwoodie, 1981).
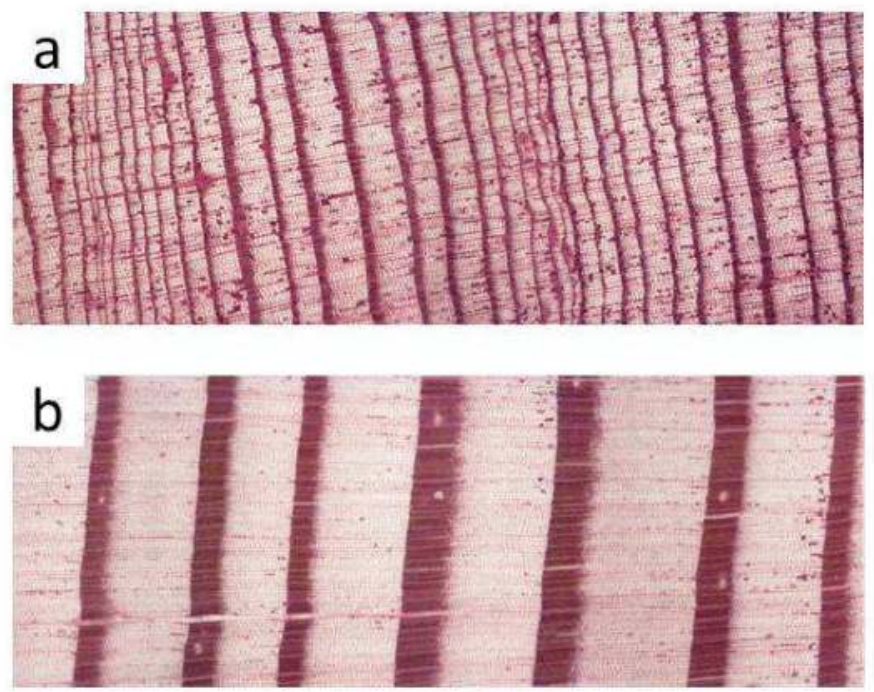

Fig. 7. Widths of xylem rings in European larch, with different proportions of early wood and late wood. 
Of the wood properties that affect quality, basic density is one of the most important because it determines its utilization in sawmills, manufacturing factories, cellulose plants and as planks. Several factors influence the variability in basic density: site, climate, geographic location, species, age and silviculture. However, tree vitality also has a major effect on wood quality and properties; the relationship among all this parameters therefore deserves deeper investigation.

\section{Relationship among the number of cells in xylem, phloem and dormant cambium in silver fir (Abies alba Mill.) trees of different vitality}

Silver fir (Abies alba) decline has appeared in many European countries, including Slovenia, since about 1500. The exact cause of silver fir decline is still not satisfactorily explained; however, it has been interpreted as a complex disease due to the interaction of several unfavourable factors, such as drought, frost, pollution, competition among trees, soil acidification, inappropriate silvicultural treatments, insects, pathogens etc (e.g., Bauch, 1986; Dobbertin, 2005; Fink, 1986; Schweingruber, 1986; Torelli et al., 1986).

Decline is characterized by reduced cambial production, especially towards the xylem, shorter cambial activity and crown damage, including needle loss and yellowing foliage (Fig. 8, 9) (e.g. Bauch, 1986; Fink, 1986; Innes, 1993; Schmitt et al., 2003; Schweingruber, 1986; Torelli et al., 1999). Reduced wood formation often occurs prior to visual symptoms of crown decline (Torelli et al., 1986, 1999), which highlights the usefulness of assessment of a tree's current mortality risk based on growth patterns and a derived statistical mortality model that clearly identifies trees at high risk of dying (Bigler et al., 2004).

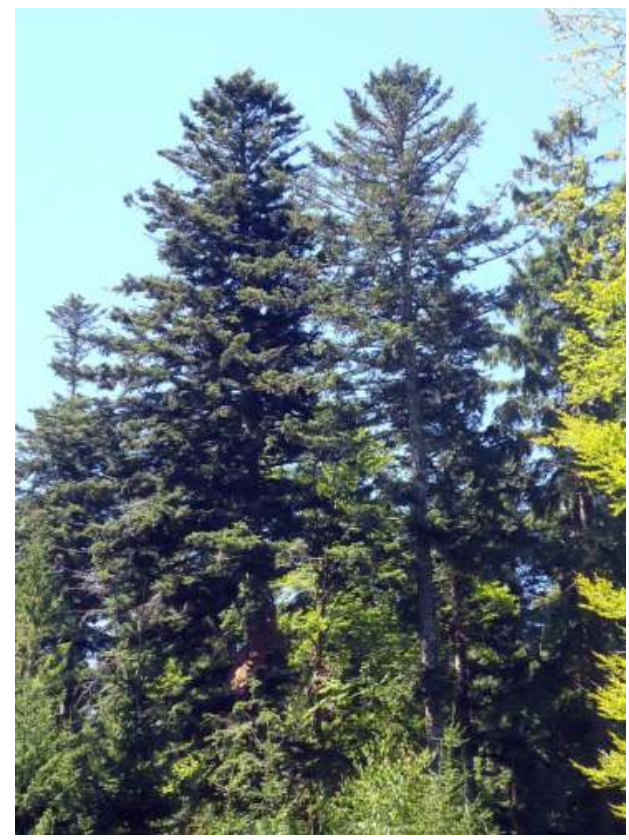

Fig. 8. Crowns of differently vital silver firs. 

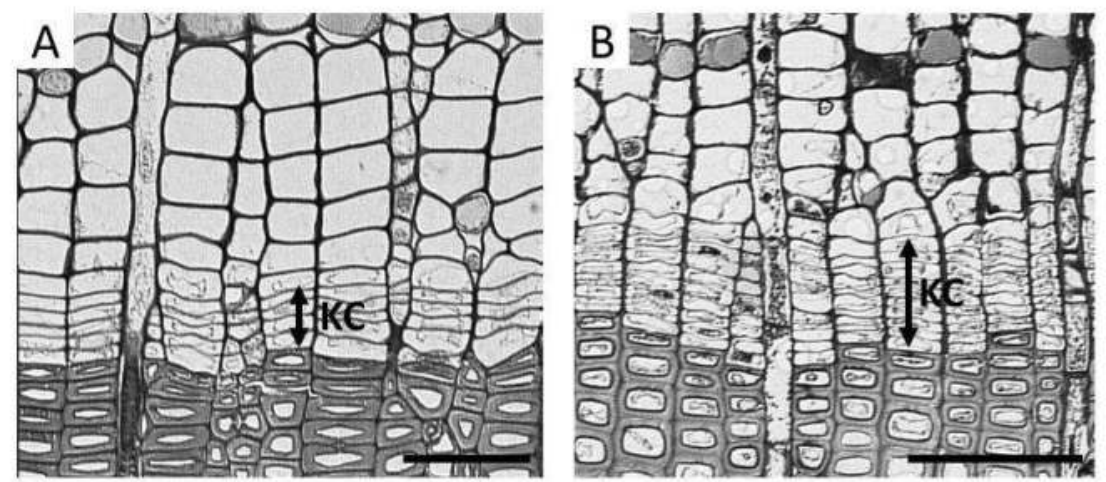

Fig. 9. Narrow cambium in declining silver fir, consisting of four to five cell layers (a) and a wide cambium in healthy silver fir consisting of about ten cell layers. KC - cambial cells, Scale bars $=50 \mu \mathrm{m}(\mathrm{A}), 100 \mu \mathrm{m}(\mathrm{B})$

Although some papers have been published concerning the anatomical structure and dynamics of secondary phloem formation (e.g., Gričar \& Čufar, 2008), the relationship among the number of cells in phloem, xylem and dormant cambium is still poorly understood. In a paper published in 2009, we investigated the anatomical structure of phloem and xylem growth rings, as well as dormant cambium in relation to vitality in 81 adult silver fir trees (Abies alba Mill.) (Gričar et al., 2009). Specifically, we investigated the number of cells produced in the current phloem growth ring, xylem growth ring and their ratio, the number of cells in the dormant cambium and the structure of the phloem growth ring, which included characterization of early phloem, late phloem and the presence, absence and continuity of tangential bands of axial parenchyma.

The silver fir (Abies alba Mill.) trees were located in an Abieti-fagetum dinaricum mixed forest at Ravnik, Slovenia (approx. $45^{\circ} 52^{\prime} \mathrm{N}, 14^{\circ} 16^{\prime} \mathrm{E}$, elevation 500-700 m). The studied trees were dominant or co-dominant, with an age of 150-180 years and DBH greater than $50 \mathrm{~cm}$. The trees belonged to a population of 269 mature trees monitored from 1987 to 2007. The health condition of the trees was assessed by determining the crown status index based on progressive needle loss and cambial electrical resistance (CER) (Torelli et al., 1999). Trees were assigned to 3 categories: A - trees with a full crown and productive cambium; B - trees with intermediate characteristics and $C$ - trees with a sparse crown and suppressed cambium (Fig. 8, 9, 10). For the study, we used microscopic slides of 81 trees of different vitality. Sample blocks $(0.5 \times 0.5 \times 1 \mathrm{~cm})$ contained inner phloem, cambium and outer xylem taken from living trees at $1.3 \mathrm{~m}$ above ground during the dormant seasons of 1999 to 2003. We used observations of transverse sections using light microscopy.

Microscopic examination of cross-sections revealed that the trees could be classified into three groups on the basis of the ratios between the number of cells in the xylem and phloem growth rings (Table 1). Group 1 (43\% of the trees) contained trees with up to four times more cells in the xylem ring than in phloem ones. The trees in group 2 (30\% of the trees) had a ratio between xylem and phloem ring from 4.0 to 10.0 , and group 3 (27\% of the trees) consisted of trees with a ratio between xylem and phloem ring greater than 10.0 (Gričar et al., 2009). 


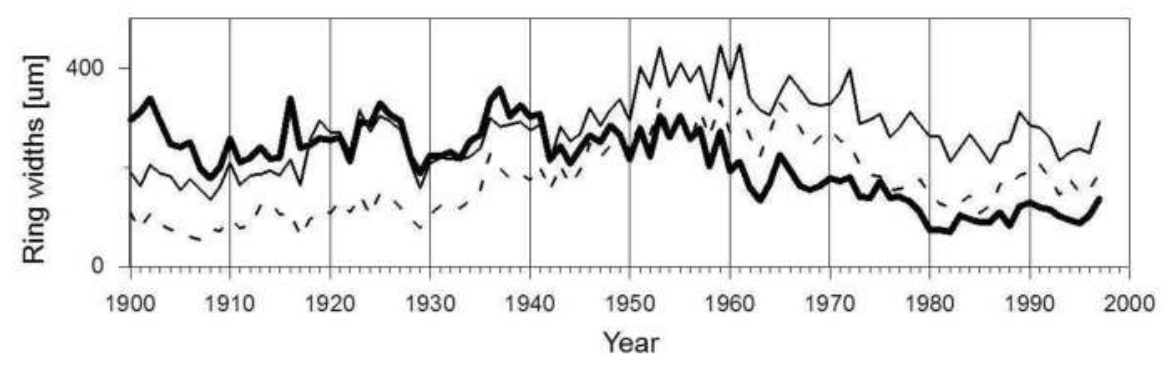

Fig. 10. Xylem ring widths of silver firs of different vitality. Category A (thin line), B (dashed line) and C (thick line) (Archives of the Chair of Wood Technology, Department of Wood Science and Technology, Biotechnical Faculty, University of Ljubljana) (Gričar, 2006).

\begin{tabular}{|c|c|c|c|c|c|}
\hline \multirow[t]{2}{*}{ Group } & \multirow[t]{2}{*}{ Ratio XR:PR } & \multirow{2}{*}{$\begin{array}{l}\text { No. of trees } \\
(\%)\end{array}$} & \multicolumn{2}{|c|}{ No. of cell layers } & \multirow[t]{2}{*}{ Structure of PR } \\
\hline & & & XR & PR & \\
\hline 1 & $<4.0: 1$ & $34(43 \%)$ & $3-26$ & $3-7$ & $\begin{array}{l}\text { AP missing or discontinuous, EP } \\
1-5 \text { or }>5 \text { cells wide, LP } 1-3 \text { cells } \\
\text { wide or absent }\end{array}$ \\
\hline 2 & (4.0-10.0): 1 & $24(30 \%)$ & $25-80$ & $5-9$ & $\begin{array}{l}\text { AP discontinuous or continuous, } \\
\text { EP 2-4 cells wide, LP present }\end{array}$ \\
\hline 3 & $>10.0: 1$ & $23(27 \%)$ & $60-144$ & $6-12$ & One or two bands of AP \\
\hline
\end{tabular}

Table 1. Characteristics of tissues in three groups of trees with different ratios between xylem and phloem growth ring widths in terms of number of cells (XR:PR). XR - xylem growth ring, $\mathrm{PR}$ - phloem growth ring, AP - axial parenchyma, EP - early phloem, LP - late phloem (Gričar et al., 2009)

We confirmed that the structure and width of the phloem are closely related in silver fir (Fig. 11). Early phloem is in general 2-5 layers of cells wide and is less dependent on tree vitality whereas late phloem is subject to higher alterations in the width and type of cells. The occurrence and amount of axial parenchyma varies in accordance with the width of the phloem ring: a) it can be absent or scarce when rings are very narrow; b) present as one, more or less continuous, tangential band between early phloem and late phloem, as observed in the majority of phloem rings; or c) also forming an additional, second, discontinuous tangential band in the late phloem of very wide rings. The cambium of vital trees normally produces more xylem than phloem cells. The ratio between xylem and phloem declines with decreased vitality of trees. Only in extreme cases can the phloem ring be wider than the xylem one. The numbers of cells in phloem, xylem and dormant cambium are correlated in silver fir. Information on the width and structure of phloem rings, as well as on the relation between xylem, phloem and dormant cambium could provide additional criteria for determining tree vitality (Gričar et al., 2009).

Inspection of the current condition of the investigated trees revealed that more than half of the trees $(62 \%)$ with a ratio between phloem and xylem increments lower than $4: 1$, with 
a very narrow xylem (about 20 cell layers) and phloem only 3-5 cell layers wide, died in the years following the sampling of tissues for our analyses. Our results suggest that the ratio between xylem and phloem, as well as the widths of xylem, phloem and dormant cambium, are related and indicate the health condition of a tree. They could therefore be used for assessment of the vitality of silver firs. This information could be beneficial in forest management practice, for planning the cutting of non-vital trees with poor survival prognosis and for identifying and promoting healthy and productive ones (Gričar et al., 2009).

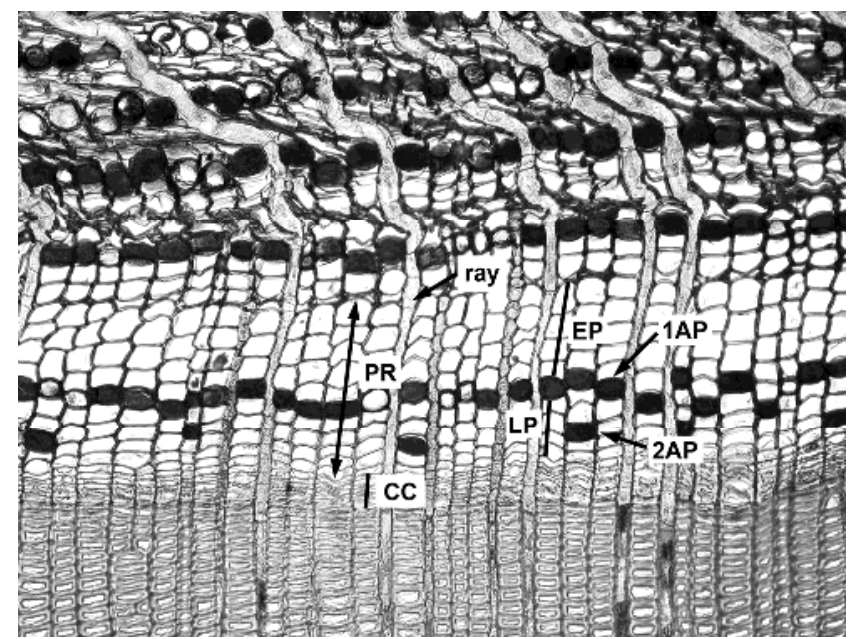

Fig. 11. Cross-section of a phloem growth ring in silver fir. PR - phloem ring, EP - early phloem sieve cells, LP - late phloem sieve cells, 1AP - first band of axial parenchyma, 2AP second band of axial parenchyma in late phloem, CC - cambium

Since the study in silver firs gave fairly encouraging results, we tested whether similar relations can also be found in ring-porous species, such as pedunculate oak (Quercus robur).

\section{Cambial productivity and widths of xylem and phloem increments in pedunculate oak (Quercus robur L.) trees of different vitality}

In Slovenia, oaks (Quercus robur L. and Quercus sessiliflora Salisb.) are economically and ecologically very important wood species and represent about $7 \%$ of the entire wood stock (Zavod za gozdove Slovenije, 2010). In the case of pedunculate oak, the lowland forest area has been shrinking, due to human settlement in the past, intensive and unplanned silvicultural and agricultural exploitation of the land and conflicts of interest, so only a few lowland oak forest stands have managed to survive (Kadunc, 2010; Žibert, 2006). Similarly as in many European countries, a trend of decreasing vitality of pedunculate oak has been observed in most sites in recent decades. In 2007, pedunculate and sessile oak had the highest share of damaged and dead trees; i.e., 35.2\% of the analysed tree species. The highest defoliation of pedunculate and sessile oak was observed in 2005. The condition of these species is characterised by some recuperation in 2006 and another increase in 2007 (UNECE, 2008). 
One of the main reasons for decreasing vitality of pedunculate oak in Slovenia is ascribed to a lowering of the ground water level due to changes in climatic conditions and unsuitable artificial melioration of land for agricultural purposes (Kadunc, 2010). Namely, numerous drainage ditches were excavated in 19th century. The most obvious response of oaks to the changing environmental (hydrological) conditions is seen in the reduced wood increment, which is closely related to the structure of wood and its quality (Fig. 12).

Oak wood is considered to be very aesthetic due to its specific anatomical structure (texture) and colour. Since it also has good mechanical and durability properties, it is used for high value sawn wood products. A major factor in the utilization of wood is the degree of variation of wood properties at different scales. Variations are the result of site-to site differences in wood, population-level differences within a site and within a single tree (Gasson, 1987; Leal et al., 2007, 2008; Lei et al., 1996; Panshin \& de Zeeuw, 1980; Zhang, 1997).

In addition to major economic consequences in these areas, the ecological issues associated with the decreasing vitality of pedunculate oak stands cannot be neglected. From a physiological point of view, wood tissues in trees perform several functions simultaneously, of which the two most important are to provide mechanical support and water transport. Different cell types, their morphological characteristics and their proportion in the xylem growth ring affect the survival and efficiency of the living tree. Vessel diameter, area and percentage conductive area strongly influence the amount of water that can be transported in the living tree, and so the larger the proportion of the ring occupied by conductive elements, the less tissue is available for supporting, strengthening and storage. Any changes in the proportion among different cell types therefore very likely modify the hydraulic and mechanical properties of wood (Tyree \& Zimmermann, 2002).

The relationship among number of cells in phloem, xylem and dormant cambium in oak is still poorly understood. We have hypothesised that the structure and width of the phloem increments, the ratio between the phloem and xylem increments and the width of the dormant cambium would reflect the health condition of the tree. More vital trees are expected to have much wider xylem than phloem increments, whereas in declining trees, the ratio between xylem and phloem will decrease. For that purpose, we investigated the width of the phloem growth rings, late phloem, xylem growth rings, late xylem, as well as the number of cells in the dormant cambium, in 80 adult pedunculate oaks (Quercus robur L.) of different vitality. The health condition of the oaks was defined according to the crown condition and the width of the xylem increment.

Oak trees of various vitality were sampled at a Pseudostellario-Carpinetum mixed forest in Krakovo, Slovenia ( $45^{\circ} 54^{\prime} \mathrm{N}, 1525^{\prime} \mathrm{E}$, elevation $150 \mathrm{~m}$ ). Krakovo is the largest lowland oak forest in Slovenia, which is flooded by the Krka River. It is dominated by Quercus robur, Carpinus betulus and Alnus glutinosa tree species. Sampled trees were dominant or codominant with diameter $50-60 \mathrm{~cm}$, height $25-30 \mathrm{~m}$ and age above 80 years. In December 2009 , we took micro-cores $(2.4 \times 2.4 \times 20 \mathrm{~mm})$ containing inner phloem, cambium and outer xylem taken from living trees at $1.3 \mathrm{~m}$ above the ground. The material extracted from the trees was immediately fixed, dehydrated in a graded series of ethanol and embedded in paraffin (Gričar, 2006). Observations and analysis were made on transverse sections using light microscopy.

The anatomical structure and widths of the phloem and xylem increments are closely related. In ring-porous oak, increasing ring width results in an increase in the percentage of late wood and late phloem, respectively (Fig. 12). In both cases, the widths of early phloem and early 
xylem were relatively stable as the widths of the phloem and xylem rings changed, whereas late phloem and late xylem were quite variable and increased with ring width (phloem R2 = 0.597; xylem R2 = 0.955) (Fig. 13). Other researchers have also found that the late wood portion in oak tends to increase with increased ring width, whereas the width of early wood is more or less constant (Phelps \& Workman, 1994; Rao et al., 1997; Zhang, 1997). The reason is in their completely different anatomical structure and, consequently, their densities, which are much higher in late wood (ca $800 \mathrm{~kg} / \mathrm{m}^{3}$ ) than in early wood (ca $560 \mathrm{~kg} / \mathrm{m}^{3}$ ) (Guilley et al., 1999). Namely, the diameter of late wood vessels is much smaller and the proportion of fibers is higher. The total ring density of oak is influenced by variation in the late wood structure and by changes in the proportion of late wood to early wood.
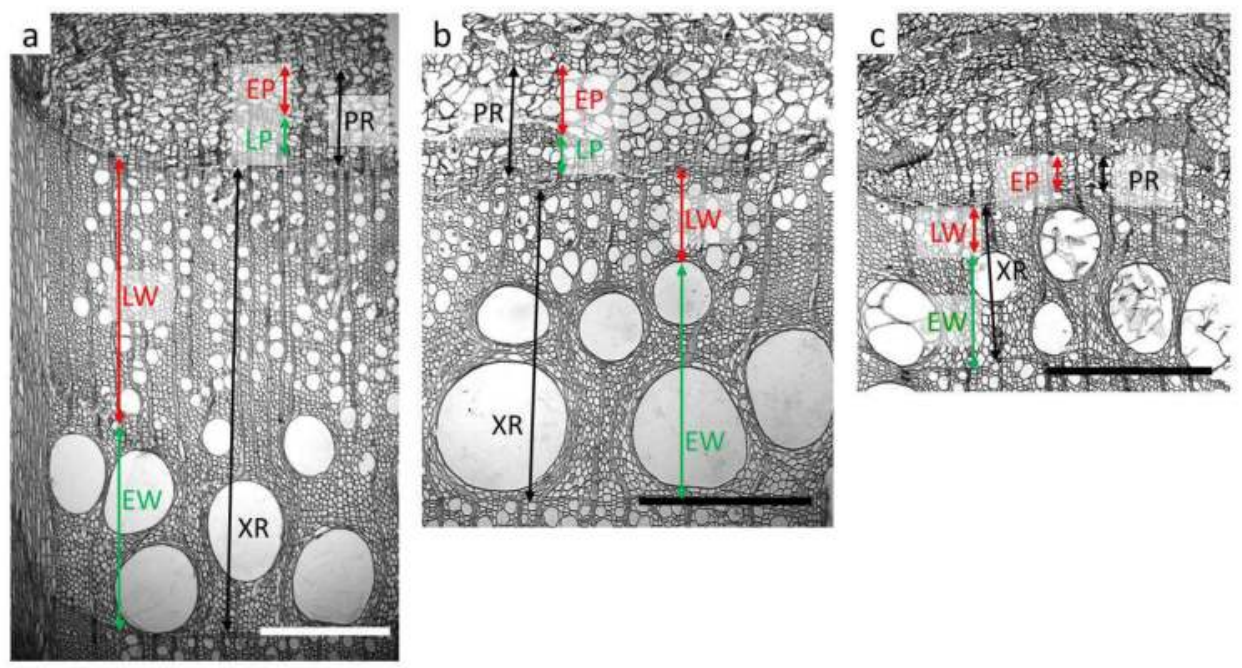

Fig. 12. Ring width and wood structure in ring-porous oaks of different vitality are closely related. XR - xylem increment, EW - early wood, LW - late wood, PR - phloem increment, $\mathrm{EP}$ - early phloem, LP - late phloem, Scale bars $=500 \mu \mathrm{m}$
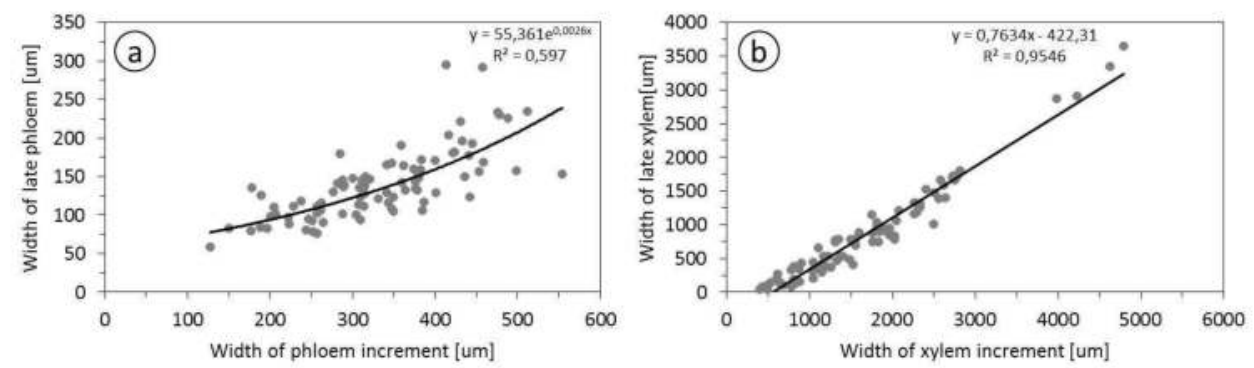

Fig. 13. Relationship between: (a) widths of late phloem and phloem increments and (b) widths of late xylem and xylem increments. 
The cambium of vital trees normally produces more xylem than phloem cells. In trees with diminished vitality, xylem production is reduced and, consequently, the ratio between the xylem and phloem increment becomes progressively smaller. Only in extreme cases can the phloem increment be wider than the xylem one (Larson, 1994; Panshin \& de Zeeuw, 1980). Of 86 sampled trees, the ratio between phloem and xylem in $40 \%$ of them was from $9 \%$ to $20 \%$, in $50 \%$ of sampled oaks the ratio between phloem and xylem was from $21 \%$ to $40 \%$, and only in 4 trees was the ratio higher than $50 \%$. The xylem increments in this case were narrow; i.e., below $1000 \mu \mathrm{m}$. We found a high negative correlation between the ratio of phloem to xylem and the width of xylem increment $(\mathrm{R} 2=0.724)$, whereas no such relation was found with the width of the phloem increment (Fig. 14). However, unlike in the case of silver fir, the phloem increment in pedunculate oak was smaller than the xylem one in all sampled trees.
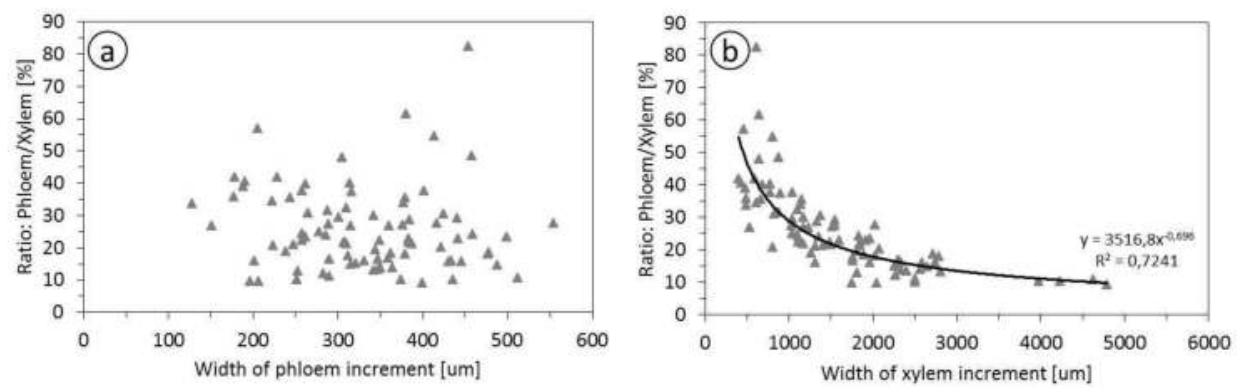

Fig. 14. Ratio between phloem and xylem increments in relation to phloem (a) and xylem (b) ring widths.

The widths of phloem and xylem and the number of cells in the dormant cambium were shown to be positively correlated. The variability in the widths of increments was higher in the xylem $(400-4660 \mu \mathrm{m})$ than in the phloem $(155-518 \mu \mathrm{m})$. In $25 \%$ of sampled oaks, the xylem increment was 400-1000 $\mu \mathrm{m}$ wide, in 44\% 1000-2000 $\mu \mathrm{m}$ wide, in 24\% 2000-3000 $\mu \mathrm{m}$ wide and in $7 \% 3000-4660 \mu \mathrm{m}$ wide. In the case of phloem, $37 \%$ of oaks had an increment from $160-300 \mu \mathrm{m}, 35 \%$ of them from $300-400 \mu \mathrm{m}$ and $28 \%$ from $400-518 \mu \mathrm{m}$. We found a positive relationship between the width of phloem increments and the number of cells in the dormant cambium $(\mathrm{R} 2=0.320)$, between the width of xylem increments and the number of cells in the dormant cambium $(\mathrm{R} 2=0.561)$ and between the width of phloem and xylem increments $(\mathrm{R} 2=0.351)$ (Fig. 15). The highest correlation was thus between the xylem increment and the number of cells in the dormant cambium.

We can summarize that:

- The widths of phloem and xylem increments and the number of cells in the dormant cambium are correlated in pedunculate oak.

- The widths of early phloem and early xylem are less dependent on tree vitality; whereas late phloem and late xylem are subject to higher alterations in width.

- The cambium of oak produces more xylem than phloem cells.

- The ratio between phloem and xylem increment declines with decreased vitality of trees. 
The study on ring-porous pedunculate oak therefore confirms the findings obtained from coniferous silver fir trees. Information on the width and structure of xylem and phloem increments, as well as the number of cells in the dormant cambium, could indeed provide additional criteria for determining tree vitality.
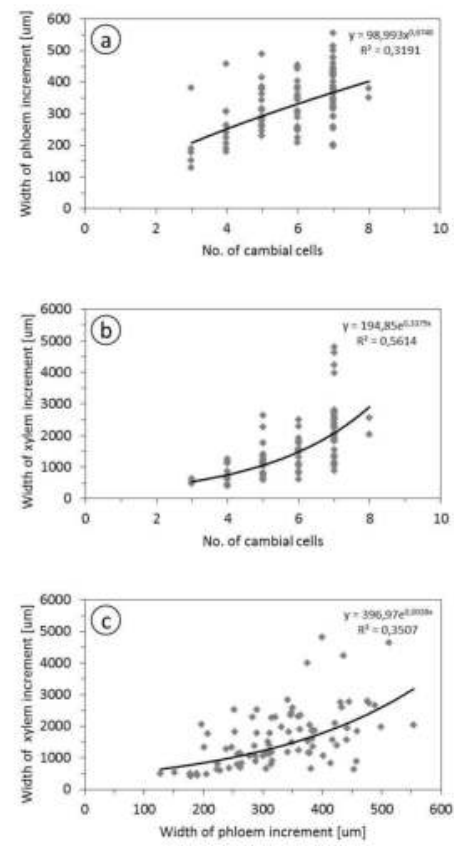

Fig. 15. Relationship between: (a) width of the phloem increment and number of cells in the dormant cambium, (b) width of the xylem increment and number of cells in the dormant cambium and (c) width of the phloem increment and width of the xylem increment in oak.

\section{Conclusions}

The anticipated environmental change is one of the main factors threatening the health condition of the economically most important tree species; economically essential forest stands are therefore potentially endangered. Knowledge of a species' growth characteristics and the effect that climatic variables and silvicultural management decisions have on tree growth is obviously a key issue for assessing and preserving the sustainability of forests (UN-ECE, 2008). Radial growth patterns have been shown to be valuable indicators of tree health condition. The width and structure of xylem growth rings are a source of information about past and present factors affecting development processes in an individual tree. Tree vitality also has a major effect on wood quality and properties. Information on the width and structure of xylem and phloem increments, as well as the number of cells in the dormant cambium could provide additional criteria for determining tree vitality. Indicators of tree health and vitality need to be accurate and reliable, but also cheap and easy to use. The proposed indicators comply with these desirable characteristics. Since vital forest 
resources are the basis of sustainable forest management and the production of quality timber, early identification of trees with an increased risk of dying could help assess and manage the health condition of forest stands in the future.

\section{Acknowledgements}

Thanks to Špela Jagodic from the Slovenian Forestry Institute for her invaluable help in the field and laboratory. The work was supported by the Slovenian Research Agency, programme P4-0107 and projects L7-2393 and V4-0496.

\section{References}

Bauch, J. (1986). Characteristics and Response of Wood in Declining Trees from Forests Affected by Pollution. IAWA Bulletin n.s., Vol.7, No.4, (December 1986), pp. 269276, ISSN 0928-1541

Beck, W. (2009). Growth Patterns of Forest Stands - The Response towards Pollutants and Climatic Impact. iForest - Journal of Biogeosciences and Forestry, Vol.2, (January 2009), pp. 4-6, ISSN 1971-7458

Berg, L.R. (2008). Introductory Botany: Plants, People and the Environment, (second edition), Thomson Brooks/Cole, ISBN-10 0534466699, ISBN-13 9780534466695, Belmont, California, USA

Bigler, C. \& Bugmann, H. (2004). Assessing the Performance of Theoretical and Empirical Tree Mortality Models Using Tree-Ring Series of Norway Spruce. Ecological Modelling, Vol.174, No.3, (May 2004), pp. 225-239, ISSN 0304-3800

Bigler, C.; Gričar, J.; Bugmann, H. \& Čufar, K. (2004). Growth Patterns as Indicators of Impending Tree Death in Silver Fir. Forest Ecology and Management, Vol.199, No.2-3, (October 2004), pp. 183-190, ISSN 0378-1127

Chaffey, N. (2002). Introduction, In: Wood Formation in Trees: Cell and Molecular Biology Techniques, N. Chaffey, (Ed.), 1-8, Taylor \& Francis, ISBN-10 0415272157, ISBN-13 978-0415272155, London and New York

Coops, N.C.; Stone, C.; Culvenor, D.S. \& Chisholm, L. (2004). Assessment of Crown Condition in Eucalypt Vegetation by Remotely Sensed Optical Indices. Journal of Environmental Quality, Vol.33, No.3, (May 2004), pp. 956-964, ISSN 0047-2425 (print version), ISSN 1537-2537 (electronic version)

Dinwoodie, J.M. (1981). Timber, Its Nature and Behaviour, Van Nostrand Reinhold, ISBN 0442304455, New York

Dobbertin, M. (2005). Tree Growth as Indicator of Tree Vitality and Tree Reaction to Environmental Stress: A Review. European Journal of Forest Research, Vol.124, No.4, (December 2005), pp. 319-333, ISSN 1612-4669 (print version), ISSN 1612-4677 (electronic version)

Ferretti, M.; König, N.; Rautio, P. \& Sase, H. (2009). Quality Assurance (QA) in International Forest Monitoring Programmes: Activity, Problems and Perspectives from East Asia and Europe. Annals of Forest Science, Vol.66, No.4, (June 2009), pp. 403 -412, ISSN 1286-4560 (print version), ISSN 1297-966X (electronic version)

Fink, S. (1986). Microscopical Investigations on Wood Formation and Function in Diseased Trees. IAWA Bulletin n.s., Vol.7, No.4, (December 1986), pp. 351-355, ISSN 09281541 
Frampton, C.M.; Pekelharing, C.J. \& Payton, I.J. (2001). A Fast Method for Monitoring Foliage Density in Single Lower-Canopy Trees. Environmental Monitoring and Assessment, Vol.72, No.3, (December 2001), pp. 227-234, ISSN 0167-6369 (print version), ISSN 1573-2959 (electronic version)

Franklin, J.F.; Shugart, H.H. \& Harmon, M.E. (1987). Tree Death as an Ecological Process. The Causes, Consequences, and Variability of Tree Mortality. BioScience, Vol.37, No.8, (September 1987), pp. 550-556, ISSN 0006-3568

Fritts, H.C. (1976). Tree Rings and Climate, Academic Press, ISBN 0122684508 / 0-12-268450-8, London, New York and San Francisco

Gasson, P. (1987). Some Implications of Anatomical Variations in the Wood of Pedunculate Oak (Quercus Robur L.), Including Comparisons with Common Beech (Fagus Sylvatica L.). IAWA Bulletin n.s., Vol.8, No.8, (June 1987), pp. 149-166, ISSN 09281541

Ghosh, S. \& Innes, J.L. (1995). Combining Field and Control Team Assessments to Obtain Error-Estimates for Surveys of Crown Condition. Scandinavian Journal of Forest Research, Vol.6, No.1-4, (January 1995), pp. 264-270, ISSN 0282-7581 (print version), ISSN 1651-1891 (electronic version)

Gorišek, Ž. (2009). Les : zgradba in lastnosti : njegova variabilnost in heterogenost, Reviewed University and Academic Textbook, Department of Wood Science and Technology, Biotechnical Faculty, University of Ljubljana, ISBN 978-961-6144-28-5, Ljubljana, Slovenia, (in Slovenian language)

Gričar, J. (2006). Effect of Temperature and Precipitation on Xylogenesis in Silver Fir (Abies Alba) and Norway Spruce (Picea Abeis), Doctoral Dissertation, Department of Wood Science and Technology, Biotechnical Faculty, University of Ljubljana, Ljubljana, Slovenia, (in Slovenian language)

Gričar, J. \& Čufar, K. (2008). Seasonal Dynamics of Phloem and Xylem Formation in Silver Fir and Norway Spruce as Affected by Drought. Russian Journal of Plant Physiology, Vol.55, No.4, (July 2008), pp. 538-543, ISSN 1021-4437 (print version), ISSN 16083407 (electronic version)

Gričar, J. (2009). Significance of Intra-Annual Studies of Radial Growth in Trees, In: TRACE Tree Rings in Archaeology, Climatology and Ecology, Volume 7: Proceedings of the Dendrosymposium 2008, April 27th - 30th, 2008 in Zakopane, Poland, R.J. Kaczka et al., (Eds.), 18-25, GFZ German Research Centre for Geoscience, ISSN 1610-0956, Potsdam, Germany

Gričar, J.; Krže, L. \& Čufar, K. (2009). Relationship among Number of Cells in Xylem, Phloem and Dormant Cambium in Silver Fir (Abies Alba Mill.) Trees of Different Vitality. IAWA Journal, Vol.30, No.2, (June 2009), pp. 121-133, ISSN 0928-1541

Groover, A.T. (2005). What Genes Make a Tree a Tree? Trends in Plant Science, Vol.10, No.5, (May 2005), pp. 210-214, ISSN 1360-1385

Guilley, É.; Hervé, J.-C.; Huber, F. \& Nepveu, G. (1999). Modelling Variability of WithinRing Density Components in Quercus Petraea Liebl. with Mixed-Effect Models and Simulating the Influence of Contrasting Silvicultures on Wood Density. Annals of Forest Science, Vol.56, No.6, (September 1999), pp. 449-458, ISSN 1286-4560 (print version), ISSN 1297-966X (electronic version)

Innes, J.L. (1993). Methods to Estimate Forest Health. Silva Fennica, Vol.27, No.2, (June 1993), pp. 145-157, ISSN 0037-5330 
Innes, J.L. (1993). Some Factors Affecting the Crown Condition Density of Trees in Great Britain Based in Recent Annual Surveys of Forest Condition, In: Forest Decline in the Atlantic and Pacific Region, R.E. Huettl \& D. Mueller-Dombois, (Eds.), 40-53, Springer-Verlag, ISBN 3540546405, Berlin-Heidelberg

Kadunc, A. (2010). Quality, Value Characteristics and Productivity of Pedunculate and Sessile Oak stands in Slovenia. Gozdarski vestnik, Vol.68, No.4, (May 2010), pp. 217226, ISSN 0017-2723, (in Slovenian language)

Kolb, T.E.; Wagner, M.R. \& Covington, W.W. (1994). Concepts of Forest Health: Utilitarian and Ecosystem Perspectives. Journal of Forestry, Vol.92, No.7, (July 1994), pp. 10-15, ISSN 0022-1201

Kozlowsky, T.T. \& Pallardy, S.G. (1997). Growth Control in Woody Plants, Academic Press, Inc. ISBN 0-12-424210-3, San Diego, California

Lachaud, S.; Catesson, A.M. \& Bonnemain, J.L. (1999). Structure and Functions of the Vascular Cambium. Comptes Rendus de l'Académie des Sciences. Sciences de la Vie (Life Sciences), Vol.322, No.8, (August 1999), pp. 633-650, ISSN 0764-4469

Larcher, W. (2003). Physiological Plant Ecology: Ecophysiology and Stress Physiology of Functional Groups, (fourth edition), Springer-Verlag, ISBN 3-540-43516-6, Berlin-HeidelbergNew York

Larson, P.R. (1994). The Vascular Cambium: Development and Structure, Springer-Verlag, ISBN 3540571655, Berlin-Heidelberg-New York

Leal, S.; Sousa, V.B. \& Pereira, H. (2007). Radial Variation of Vessel Size and Distribution in Cork Oak Wood (Quercus Suber L.). Wood Science and Technology, Vol.41, No.4, (April, 2007), pp. 339-350, ISSN (print version), ISSN 1432-5225 (electronic version)

Leal, S.; Nunes, E. \& Pereira, H. (2008). Cork Oak (Quercus Suber L.) Wood Growth and Vessel Characteristics Variations in Relation to Climate and Cork Harvesting. European Journal of Forest Research, Vol.127, No.1, (January 2008), pp. 33-41, ISSN 1612-4669 (print version), ISSN 1612-4677 (electronic version)

Lei, H.; Milota, M. R. \& Gartner, B.L. (1996). Between- and Within-Tree Variation in the Anatomy and Specific Gravity of Wood in Oregon White Oak (Quercus Garryana Dougl.). IAWA Journal, Vol.17, No.4, (December 2003), pp. 445-461, ISSN 0928-1541

Legg, C.J. \& Nagy, L. (2006). Why Most Conservation Monitoring Is, But Need Not Be, a Waste of Time. Journal of Environmental Management, Vol.78, No.2, (January 2006), pp. 194-199, ISSN 0301-4797

Martín-García, J.; Diez, J.J. \& Jactel, H. (2009). Towards Standardised Crown Condition Assessment in Poplar Plantations. Annals of Forest Science, Vol.66, No.3, (April-May 2009), pp. 308, ISSN 1286-4560 (print version), ISSN 1297-966X (electronic version)

Mauseth, J.D. (1988). Plant Anatomy, Benjamin/Cummings Publishing Company, ISBN 0805345701 Menlo Park, California

Mizoue, N. (2002). CROCO: Semi-Automatic Image Analysis System for Crown Condition Assessment in Forest Health Monitoring. Journal of Forest Planning, Vol.8, No.1, (April 2002), pp. 17-24, ISSN 1341562X

Mizoue, N. \& Dobbertin, M. (2003). Detecting Differences in Crown Transparency Assessments between Countries Using the Image Analysis System CROCO. Environmental Monitoring and Assessment, Vol.89, No.2, (December 2003), pp. 179195, ISSN 0167-6369 (print version), ISSN 1573-2959 (electronic version) 
Panshin, A.J. \& de Zeeuw, C. (1980). Textbook of Wood Technology, (fourth edition), McGrawHill, ISBN 0070484414, New York

Phelps, J.E. \& Workman, E.C. (1994). Vessel Area Studies in White Oak (Quercus Alba L.). Wood and Fiber Science, Vol26, No.3, (July 1994), pp. 315-322, ISSN 07356161

Plomion, C.; Leprovost, G. \& Stokes, A. (2001). Wood Formation in Trees. Plant Physiology, Vol.127, No.4, (December 2001), pp. 1513-1523, ISSN 0032-0889 (print version), ISSN 1532-2548 (electronic version)

Rao, R.V.; Aebisher, D.P. \& Denne, M.P. (1997). Latewood Density in Relation to Wood Fibre Diameter, Wall Thickness, and Fibre and Vessel Percentages in Quercus Robur L. IAWA Journal, Vol.18, No.2, (June 1997), pp. 127-138, ISSN 0928-1541

Savidge, R.A. (2001). Intristic Regulation of Cambial Growth. Journal of Plant Growth Regulation, Vol.20, No.1, (March 2001), pp. 52-77, ISSN 0721-7595 (print version), ISSN 1435-8107 (electronic version)

Schmitt, U.; Grünwald, C.; Gričar, J.; Koch, G. \& Čufar, K. (2003). Wall Structure of Terminal Latewood Tracheids of Healthy and Declining Silver Fir Trees in the Dinaric Region, Slovenia. IAWA Journal, Vol.24, No.1, (March 2003), pp. 41-51, ISSN 09281541

Schweingruber, F.H. (1986). Abrupt Growth Changes in Conifers. IAWA Bulletin n.s., Vol.7, No.4, (December 1986), pp. 277-283, ISSN 0928-1541

Shigo, A.L. (1986). A New Tree Biology, Shigo \& Trees Associates, ISBN 0943563127, Durham, New Hampshire

Solberg, S. \& Strand, L. (1999). Crown Density Assessments, Control Surveys and Reproducibility. Environmental Monitoring and Assessment, Vol.56, No.1, (May 1999), pp. 75-86, ISSN 0167-6369 (print version), ISSN 1573-2959 (electronic version)

Stone, C.; Wardlaw, R.F.; Carnegie, A., Wyllie, R. \& De Little, D. (2003). Harmonization of Methods for the Assessment and Reporting of Forest Health in Australia - A Starting Point. Australian Forestry, Vol.66, No.4, (December 2009), pp. 233-246, ISSN, 0004-9158

Taiz, L. \& Zeiger, E. (2002). Plant Physiology, (third edition), Sinauer Associates Inc. Publishers, ISBN 0-87893-823-0, Sunderland, Massachusetts

Torelli, N.; Čufar, K. \& Robič, D. (1986). Some Wood Anatomical, Physiological and Silvicultural Aspects of Silver Fir Dieback in Slovenia. IAWA Bulletin n.s., Vol.7, No.4, (December 1986), pp. 343-350, ISSN 0928-1541

Torelli, N.; Shortle, W.C.; Čufar, K.; Ferlin, F. \& Smith, K.T. (1999). Detecting Changes in Tree Health and Productivity of Silver Fir in Slovenia. European Journal of Forest Pathology, Vol.29, No.3, (June 1999), pp. 187-197. ISSN 0300-1237 (print version), ISSN 1573-846 (electronic version)

Tyree, M.T. \& Zimmermann, M.H. (2002). Xylem Structure and the Ascent of Sap, SpringerVerlag, ISBN 3-540-43354-6, Berlin-Heidelberg-New York

UN-ECE (2008). The Condition of Forests in Europe: 2006 Executive Report. Institute for World Forestry, ISSN 1020-587X, Hamburg, Germany

Vos, P.; Meelis, E. \& Ter Keurs, W.J. (2000). A Framework for the Design of Ecological Monitoring Programs as a Tool for Environmental and Nature Management. Environmental Monitoring and Assessment, Vol.61, No.3, (April 2000), pp. 317-344, ISSN 0167-6369 (print version), ISSN 1573-2959 (electronic version) 
Zavod za gozdove Slovenije. (2010). Poročilo zavoda za gozdove Slovenije o gozdovih za leto 2009. Ljubljana, (in Slovenian language), 14.07.2011; Available from

http://www.zgs.gov.si/fileadmin/zgs/main/img/PDF/LETNA_POROCILA/Porgozd10_ Solc1.pdf

Zhang, S.Y. (1997). Variations and Correlations of Various Ring Width and Ring Density Features in European Oak: Implications in Dendroclimatology. Wood Science and Technology, Vol.31, No.1, (February 1997), pp. 63-72, ISSN (print version), ISSN 1432-5225 (electronic version)

Waring, R. H.; Thies, W. G. \& Muscato, D. (1980). Stem Growth per Unit of Leaf Area: A Measure of Tree Vigour. Forest Science, Vol.26, No.1, (March 1980), pp. 112-117, ISSN 0015-749X

Waring, R. H. (1987). Characteristics of Trees Predisposed to Die. BioScience, Vol.37, No.8, (September 1987), pp. 569-574, ISSN 0006-3568

Wimmer, R. (2002). Wood Anatomical Features in Tree-Rings as Indicators of Environmental Change. Dendrochronologia, Vol.20, No.1-2, (January 2002), pp. 2136, ISSN 1125-7865

Wodzicki, T.J. (2001). Natural Factors Affecting Wood Structure. Wood Science and Technology, Vol.35, No.1-2, (April 2001), pp. 5-26, ISSN (print version), ISSN 14325225 (electronic version)

Žibert, F. (2006). Stand Structure in Virgin Forest Reserve Krakovo and Managed Forest, Graduation Thesis - Higher Professional Studies, Department of Forestry and Renewable Forest Resources, Biotechnical Faculty, University of Ljubljana, Ljubljana, Slovenia, (in Slovenian language) 


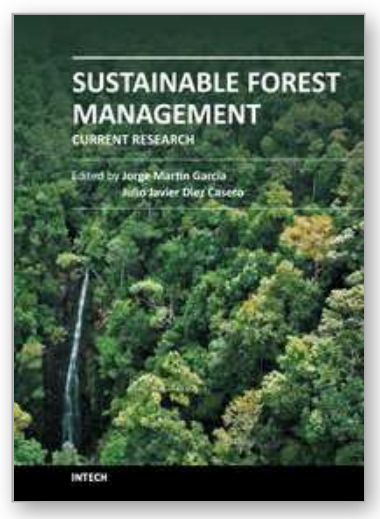

\author{
Sustainable Forest Management - Current Research \\ Edited by Dr. Julio J. Diez
}

ISBN 978-953-51-0621-0

Hard cover, 454 pages

Publisher InTech

Published online 23, May, 2012

Published in print edition May, 2012

Sustainable forest management (SFM) is not a new concept. However, its popularity has increased in the last few decades because of public concern about the dramatic decrease in forest resources. The implementation of SFM is generally achieved using criteria and indicators (C\&I) and several countries have established their own sets of C\&I. This book summarises some of the recent research carried out to test the current indicators, to search for new indicators and to develop new decision-making tools. The book collects original research studies on carbon and forest resources, forest health, biodiversity and productive, protective and socioeconomic functions. These studies should shed light on the current research carried out to provide forest managers with useful tools for choosing between different management strategies or improving indicators of SFM.

\title{
How to reference
}

In order to correctly reference this scholarly work, feel free to copy and paste the following:

Jožica Gričar (2012). Cambial Cell Production and Structure of Xylem and Phloem as an Indicator of Tree Vitality: A Review, Sustainable Forest Management - Current Research, Dr. Julio J. Diez (Ed.), ISBN: 978-95351-0621-0, InTech, Available from: http://www.intechopen.com/books/sustainable-forest-management-currentresearch/cambial-cell-production-and-structure-of-xylem-and-phloem-as-an-indicator-of-tree-vitality-a-review

\section{INTECH}

open science | open minds

\author{
InTech Europe \\ University Campus STeP Ri \\ Slavka Krautzeka 83/A \\ 51000 Rijeka, Croatia \\ Phone: +385 (51) 770447 \\ Fax: +385 (51) 686166 \\ www.intechopen.com
}

\author{
InTech China \\ Unit 405, Office Block, Hotel Equatorial Shanghai \\ No.65, Yan An Road (West), Shanghai, 200040, China \\ 中国上海市延安西路65号上海国际贵都大饭店办公楼405单元 \\ Phone: +86-21-62489820 \\ Fax: +86-21-62489821
}


(C) 2012 The Author(s). Licensee IntechOpen. This is an open access article distributed under the terms of the Creative Commons Attribution 3.0 License, which permits unrestricted use, distribution, and reproduction in any medium, provided the original work is properly cited. 